\title{
Terminology and Nomenclature
}

\section{NOMENCLATURE OF GLUCOSE-6-PHOSPHATE DEHYDROGENASE IN MAN*}

\begin{abstract}
The World Health Organization convened in Geneva from 5 to 10 December 1966 a Scientific Group on Standardization of Procedures for the Study of Glucose-6-Phosphate Dehydrogenase ${ }^{1}$ (EC 1.1.1.49; D-glucose-6-phosphate : NAPD oxidoreductase; G6PD). Variants of this enzyme have attracted international attention both as causes of various haemolytic disorders and as useful genetic markers in man. In the course of the meeting the variants of this enzyme thus far described were extensively reviewed. There was unanimous agreement that a consistent system of nomenclature would be desirable, and that as G6PD variants were only one example of similar polymorphisms in man, a nomenclature should be devised which might conceivably be applied to other enzymes.

The Group included the following recommendations on nomenclature in its report, which will be published in full in World Health Organization: Technical Report Series, 1967, 366.
\end{abstract}

\section{General recommendations}

In any attempt to develop a rational nomenclature when a working nomenclature is already in existence, a certain amount of compromise is necessary to minimize changes in names of variants already widely recognized in the literature. In the case of glucose-6phosphate dehydrogenase, such a compromise has been reached by retention of the designations $\mathrm{B}, \mathrm{A}$, and $A-$, although it is realized that the use of $A$ and A - for structurally different enzymes is not ideal. The designations, however, are too well established to permit change. Otherwise, it is recommended that all existing and future variants should be given geographical or trivial names. Designations of broad geographical areas such as continents or countries should not be used. Ethnic names, family names, and further alphabetical designations should be avoided. The use of numerals should also be avoided, including those attached as suffixes to the geographical name, such as Austin-1 and Austin-2. Because current evidence indicates allelism of the genes determining the variant forms of G6PD, the nomenclature is based on this assumption.

\section{Specific recommendations}

(a) The phenotypic and genotypic symbol should be $\mathrm{Gd}$, and the $\mathrm{G}$ should be capitalized in both cases.

* A French version will be published in a later issue.

1 Members: Dr K. Betke, Federal Republic of Germany; Dr G. J. Brewer, USA; Dr H. N. Kirkman, USA (Rapporteur) Dr L. Luzzatto, Nigeria; Dr A. G. Motulsky, USA (Chairman); Dr B. Ramot, Israel (Rapporteur); Dr M. Siniscalco, Netherlands (Vice-Chairman); Secretariat: Mrs C. C. Standley, WHO (Secretary); Dr E. Beutler, USA (Temporary Adviser).
In referring to the enzyme itself, it is appropriate to use the abbreviation G6PD, such as G6PD Mediterranean.

(b) The genotypic symbol should be italicized, with the specific genetic designation being a superscript (e.g., $\left.G \cdot d^{\mathrm{B}}\right)$.

(c) The lower right-hand corner of the symbols should be left vacant for any chemical designations that may be needed in future as knowledge of the structure of the enzyme increases.

(d) Enzyme activity relative to the normal B enzyme should be indicated in the phenotypic symbol following Gd. It should be kept in mind that exogenous or environmental factors such as drugs and fava beans can alter the normal composition of the red cell population and so modify enzyme activity; the phenotypic characterization used should be as representative as possible of the usual status of enzyme activity in a given variant.

Indications of enzyme activity should be as follows:

(-) indicates $25 \%$ or less activity

$( \pm)$ indicates $25 \%-65 \%$ activity

$(+)$ indicates normal activity $(65 \%-150 \%)$

$(++)$ indicates greater than $150 \%$ activity (or at least 2 SD above the mean). This designation should be used only when genetic or biochemical evidence, or both, indicates the presence of a gene specifying a highly active G6PD enzyme. More than two plus signs can be used if desired to indicate greater activity, such as $(++++)$ for four times normal activity.

(e) In the phenotypic symbol, the enzyme activity indicator should be followed by a comma, and then by the specific name of the variant. 


\begin{tabular}{|c|c|c|c|c|c|c|c|c|c|c|c|c|c|c|c|c|}
\hline 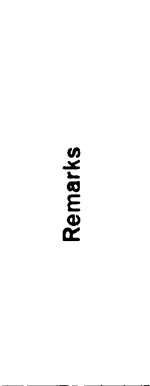 & & & 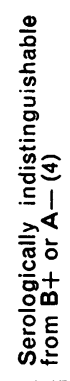 & & & & & & & & 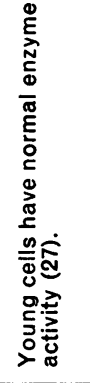 & 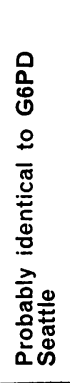 & 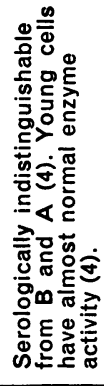 & & & 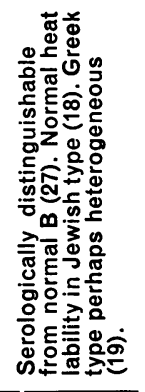 \\
\hline 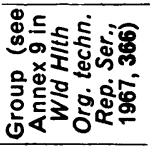 & & $\sim$ & - & - & - & - & - & - & - & - & - & $m$ & - & - & - & - \\
\hline 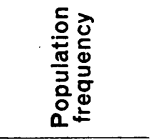 & $\begin{array}{l}\bar{\sigma} \\
\overline{3} \\
\stackrel{5}{J}\end{array}$ & 迩 & 究 & $\begin{array}{l}\stackrel{0}{\frac{\pi}{\pi}} \\
\ddot{\mathscr{L}}\end{array}$ & 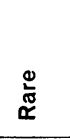 & 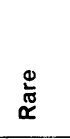 & 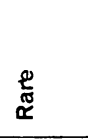 & 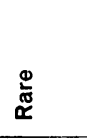 & $\begin{array}{l}\stackrel{0}{\frac{\pi}{\pi}} \\
\check{\propto ⿻}\end{array}$ & 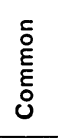 & 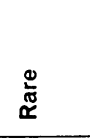 & 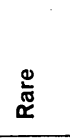 & 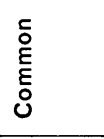 & $\begin{array}{l}\tau \\
\stackrel{0}{\xi} \\
\varepsilon \\
0\end{array}$ & 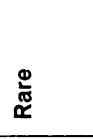 & 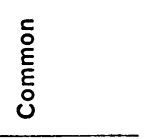 \\
\hline 동를 & 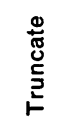 & a. & 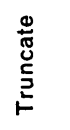 & a. & 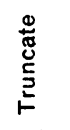 & a. & $\begin{array}{l}\frac{0}{0} \\
\frac{\pi}{0} \\
\frac{0}{0} \\
00\end{array}$ & 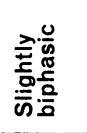 & a. & a. & 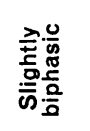 & a. & 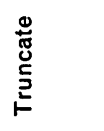 & $\begin{array}{l}\frac{0}{0} \\
\frac{\pi}{0} \\
\frac{0}{0} \\
\frac{0}{0}\end{array}$ & 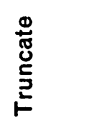 & $\begin{array}{l}\frac{0}{0} \\
\frac{\pi}{0} \\
\frac{0}{0} \\
\frac{0}{0}\end{array}$ \\
\hline 离 & $\begin{array}{l}\overline{\widetilde{\pi}} \\
\text { Eे } \\
\text { z }\end{array}$ & a. & $\begin{array}{l}\overline{\widetilde{\sigma}} \\
\underline{\xi} \\
\text { z }\end{array}$ & 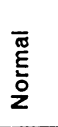 & $\begin{array}{l}\bar{\sigma} \\
\text { Ĕ } \\
\text { z }\end{array}$ & $\begin{array}{l}\overline{\widetilde{\sigma}} \\
\stackrel{\xi}{\xi} \\
\text { z }\end{array}$ & $\begin{array}{l}\bar{\sigma} \\
\text { Ẽ } \\
\text { ¿े }\end{array}$ & $\begin{array}{l}\bar{\varpi} \\
\stackrel{\varpi}{\xi} \\
\text { z }\end{array}$ & $a$ & $\begin{array}{l}\stackrel{0}{0} \\
\text { త్ }\end{array}$ & $\begin{array}{l}\bar{\varpi} \\
\text { E్ } \\
\text { z }\end{array}$ & a. & 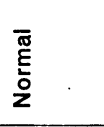 & 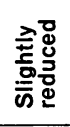 & $\begin{array}{l}\overline{\widetilde{\varpi}} \\
\text { है } \\
\text { z }\end{array}$ & 3 \\
\hline 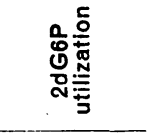 & $\stackrel{\nabla}{v}$ & a. & $\ddot{v}$ & $\dot{v}$ & $\stackrel{\nabla}{V}$ & n. & $\stackrel{+}{r}$ & $\begin{array}{l}\bar{\sigma} \\
\stackrel{5}{E} \\
\text { z }\end{array}$ & $\begin{array}{l}\bar{\sigma} \\
\stackrel{\sigma}{5} \\
\text { z }\end{array}$ & a. & $\bar{i}$ & n. & $\stackrel{\nabla}{V}$ & $\frac{10}{7}$ & + & 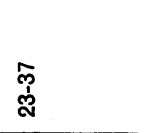 \\
\hline$\underbrace{z}_{1}$ & ণ্ণj & a. & 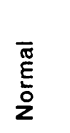 & $\bar{s}$ & $\overbrace{\tilde{j}}^{\infty}$ & 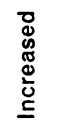 & $\stackrel{\leftrightarrow}{\circ}$ & a. & $\begin{array}{l}\overline{\widetilde{\sigma}} \\
\stackrel{\xi}{5} \\
z\end{array}$ & n. & 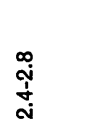 & a. & $\begin{array}{l}\overline{\text { बू }} \\
\text { Eे } \\
\text { z }\end{array}$ & 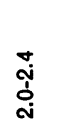 & $\stackrel{\circ}{\circ}$ & \\
\hline 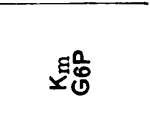 & 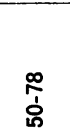 & a. & $\begin{array}{l}\overline{\tilde{\sigma}} \\
\text { है } \\
\text { zo }\end{array}$ & 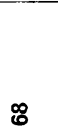 & ণัஸ் & 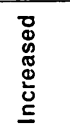 & $\mathscr{\sim}$ & 守 & $\begin{array}{l}\bar{\Phi} \\
\text { E్ } \\
\text { z }\end{array}$ & & 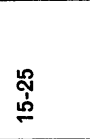 & n. & 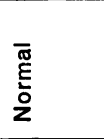 & 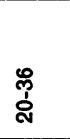 & $\bar{m}$ & $\begin{array}{l}\text { ণัँ } \\
\stackrel{2}{\circ}\end{array}$ \\
\hline 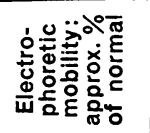 & 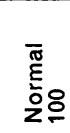 & 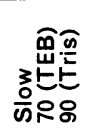 & : & 응 & $\begin{array}{l}\infty \\
3 \\
\frac{3}{\omega} \infty\end{array}$ & 胥邑 & 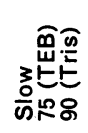 & $\begin{array}{l}30 \\
\text { oㅇํㅇ } \\
\text { क⿺辶े }\end{array}$ & 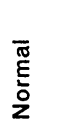 & $\begin{array}{l}\overline{\text { ब. }} \\
\text { Eे } \\
\text { z }\end{array}$ & 产ஃ & ஸั & 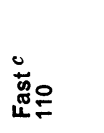 & 䓵온 & 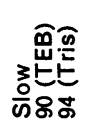 & $\begin{array}{l}\frac{\sigma}{\tilde{\sigma}} \\
\frac{0}{2}\end{array}$ \\
\hline 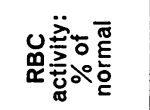 & 음 & $\stackrel{8}{\circ}$ & $\mathscr{\infty}$ & $\stackrel{2}{2}$ & $\underset{\sim}{⿰}$ & $\begin{array}{l}\stackrel{\circ}{1} \\
\dot{\sigma}\end{array}$ & 요 & $\begin{array}{l}\text { 울 } \\
\stackrel{\leftrightarrow}{\mathfrak{n}}\end{array}$ & 足 & 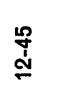 & 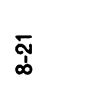 & $\stackrel{n}{\sim}$ & ণิ & $\underset{\mathfrak{g}}{\stackrel{Z}{q}}$ & o & $\hat{o}$ \\
\hline$\frac{5}{\frac{0}{\pi}}$ & $\stackrel{\substack{0 \\
\frac{0}{5}}}{>}$ & 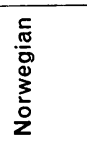 & $\begin{array}{l}\stackrel{\circ}{5} \\
\stackrel{\Phi}{z}\end{array}$ & $\begin{array}{l}\circ \\
\frac{0}{0} \\
\text { ¿ }\end{array}$ & $\begin{array}{l}\circ \\
\stackrel{0}{0} \\
2\end{array}$ & 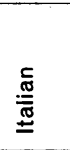 & 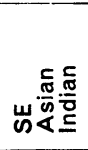 & 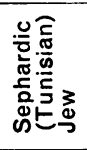 & $\begin{array}{l}\text { 음 } \\
\text { ż }\end{array}$ & 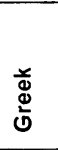 & 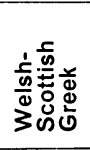 & 息胥 & $\begin{array}{l}\text { 응 } \\
\text { ¿ }\end{array}$ & ڤ⿸\zh14口 & 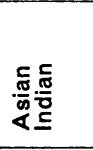 & 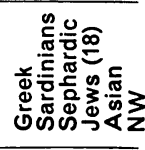 \\
\hline 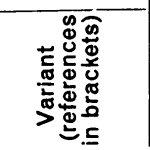 & $\begin{array}{l}\frac{m}{\pi} \\
\frac{\pi}{5} \\
\frac{0}{2}\end{array}$ & $\begin{array}{l}\bar{c} \\
\overline{0} \\
\frac{0}{0} \\
\sum_{0}^{\pi} \\
\vdots\end{array}$ & $\begin{array}{l}\text { ô } \\
\text { ज্ } \\
\varangle\end{array}$ & 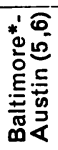 & 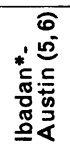 & 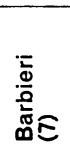 & 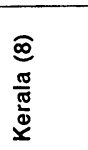 & 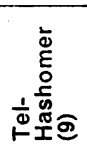 & 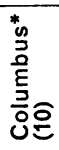 & 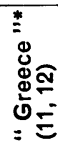 & 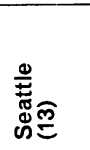 & 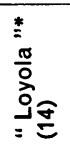 & $\frac{\sqrt{2}}{40}$ & 总 & 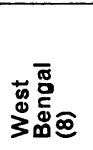 & 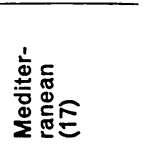 \\
\hline
\end{tabular}



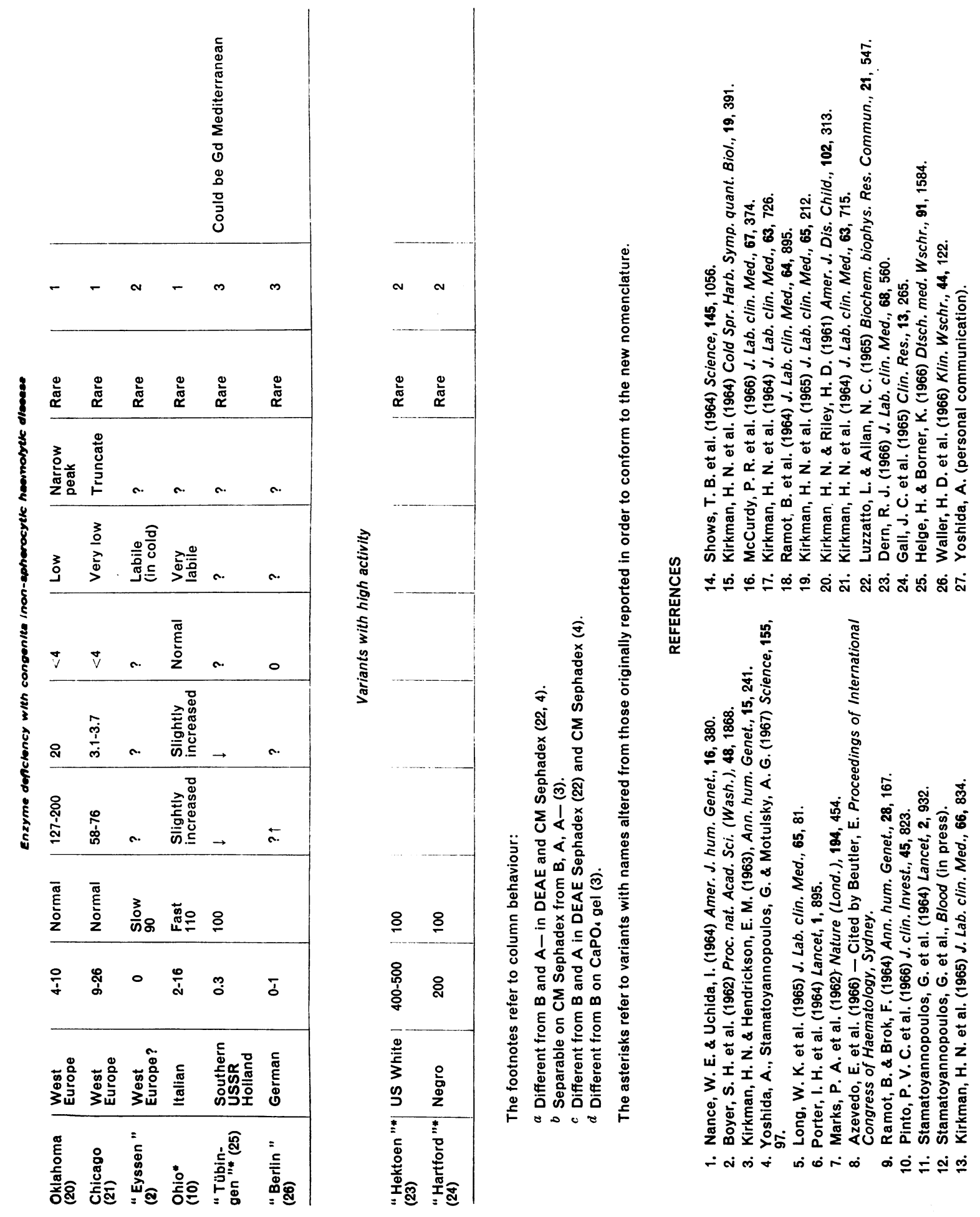

\section{.}

舟嵒

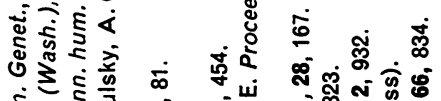

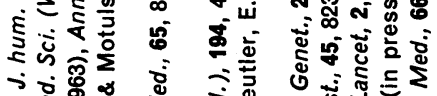

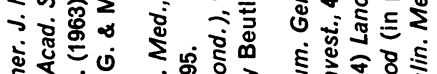

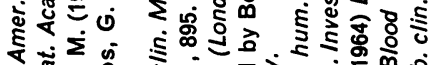

จ

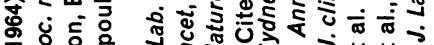

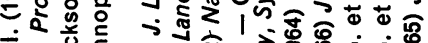

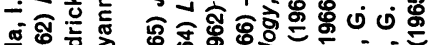

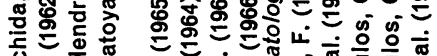

Ј

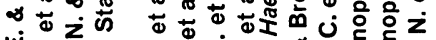

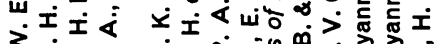

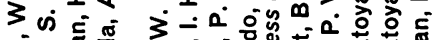
之ั

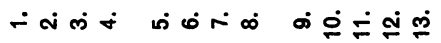


(f) The terms B, A, and A- have gained general acceptance and should be retained for the enzymes, the first two showing no enzyme deficiency and the last being the common deficiency mutant occurring primarily in Negroes. The characteristics of all three enzymes are outlined in the accompanying table.

$(g)$ The name of the common deficient enzyme variant with electrophoretic migration equal to $B$ and the characteristics outlined in the table should be: Mediterranean.

(h) The names of most other variants are given in the table.

(i) A name should not be definitively assigned to an allegedly new variant until certain characterization studies are carried out to differentiate it from known variants. ${ }^{1}$ Until such time, the name should be enclosed in quotation marks. When the mutant is characterized and established as distinct, the quotation marks should be omitted.

$(j)$ In the phenotypic characterization of a female heterozygote the actually observed phenotypic expression should be indicated, not the phenotype of inference. An oblique line can be used to separate the two names in the genotypic designations (e.g., $\left.G d^{\mathrm{A}} / G d^{\mathrm{B}}\right)$.

(k) Common isoalleles specifying slight variation in activity may possibly be demonstrated in various "normal" populations. The designation for these alleles should be enclosed in parentheses after the name of the variant in both the phenotypic and genotypic designations.

Examples of typical phenotypic and genotypic designations

General description of enzyme

Normal enzyme.

Deficient enzyme with electrophoretic mobility similar to B, occurring in polymorphic frequency in many populations.

Enzyme with near normal activity migrating faster than $B$ on electrophoresis and occurring in polymorphic frequency in Negroes. occurring in polymorphic frequency in Negroes.

A typical example of a presumably new mutant which has not been fully characterized.

A hypothetical example of isoalleles specifying slightly lation. The name of the isoallele would appear between the parentheses that have been left blank.

Typical examples of female designations. Note that one genotype can give rise to many phenotypes, depending on $\mathrm{X}$-chromosomal inactivation.
Deficient enzyme with electrophoretic mobility similar to $\mathrm{A}$, different quantitative activity in the "normal" poputhe activity of a given variant enzyme and the effect of

\begin{tabular}{|c|c|}
\hline $\begin{array}{c}\text { Phenotype } \\
\text { Males }\end{array}$ & $\begin{array}{c}\text { Genotype } \\
\text { Males }\end{array}$ \\
\hline $\mathrm{Gd}(+), \mathbf{B}$ & $G d^{\mathbf{B}}$ \\
\hline Gd(-), Mediterranean & $G d^{\text {Mediterranean }}$ \\
\hline $\mathrm{Gd}(+), \mathrm{A}$ & $G d^{\mathbf{A}}$ \\
\hline $\mathrm{Gd}(-), \mathrm{A}-$ & $G d^{\mathrm{A}-}$ \\
\hline Gd(-) “ Tübingen " & $G d$ "Tübingen" \\
\hline $\mathrm{Gd}(+), \mathrm{B}(\quad)$ & $G d^{\mathrm{B}()}$ \\
\hline Females & Females \\
\hline $\mathrm{Gd}(+), \mathbf{B}$ & $G d^{\mathrm{B}} / G d^{\mathrm{B}}$ \\
\hline $\left.\begin{array}{l}\mathrm{Gd}(+), \mathrm{AB} \\
\mathrm{GD}(+), \mathrm{A} \\
\mathrm{Gd}(+), \mathrm{B}\end{array}\right\}$ & $G d^{\mathbf{B}} / G d^{\mathbf{A}}$ \\
\hline $\left.\begin{array}{l}G d( \pm), B, A- \\
G d(+), B \\
G d(-), A-\end{array}\right\}$ & $G d^{\mathrm{B}} / G d^{\mathrm{A}-}$ \\
\hline $\mathrm{Gd}(-), \mathrm{A}-$ & $G d^{\mathrm{A}-} / G d^{\mathrm{A}-}$ \\
\hline $\left.\begin{array}{l}\mathrm{Gd}( \pm), \mathrm{A} \\
\mathrm{Gd}(+), \mathrm{A} \\
\mathrm{Gd}(-), \mathbf{A}-\end{array}\right\}$ & $G d^{\mathrm{A}-} / G d^{\mathrm{A}}$ \\
\hline $\begin{array}{l}\mathrm{Gd}( \pm), \text { B, Canton } \\
\mathrm{Gd}(-), \text { Canton } \\
\mathrm{Gd}(+), \text { B }\end{array}$ & $G d^{\mathrm{B}} / G d^{\text {Canton }}$ \\
\hline
\end{tabular}

${ }^{1}$ Described in section 3 of the report of the WHO Scientific Group on the Standardization of Procedures for the Study of Glucose-6-Phosphate Dehydrogenase (Wld Hlth Org. techn. Rep. Ser., 1967, 366). 